AL IBTIDA: JURNAL PENDIDIKAN GURU MI (2018) VOL 5 (2) : 175-190

DOI: http://dx.doi.org/10.24235/al.ibtida.snj.v5i2.2890

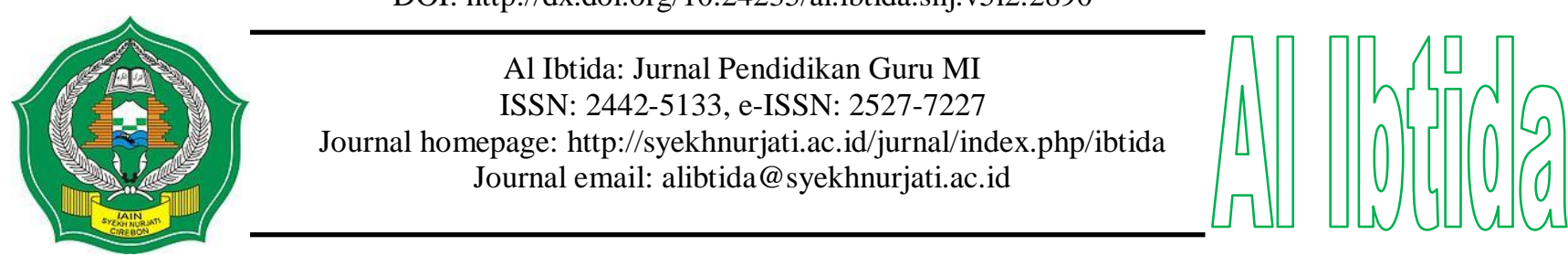

\title{
Pembelajaran Visual, Auditory dan Kinestetik Terhadap Keaktifan dan Pemahaman Konsep Matematika Siswa Sekolah Dasar
}

\author{
Nuhyal Ulia* \\ *Program Studi Pendidikan Guru Sekolah Dasar, Fakultas Keguruan dan Ilmu Pendidikan, \\ Universitas Islam Sultan Agung Semarang \\ Email: nuhyalulia@unissula.ac.id \\ Yunita Sari*** \\ **Program Studi Pendidikan Guru Sekolah Dasar, Fakultas Keguruan dan Ilmu Pendidikan, \\ Universitas Islam Sultan Agung Semarang \\ Email: yunitasari@unissula.ac.id
}

Received 14 August 2018; Received in revised form: 03 October 2018; Accepted 05 October 2018 Publish Online: 30 October 2018

\begin{abstract}
Abstrak
Tujuan penelitian ini adalah untuk mengetahui pengaruh keaktifan siswa pada Pembelajaran Model Kooperatif Learning Visual Auditory Kinestetik Terhadap Pemahaman Konsep Matematika Sekolah Dasar. Jenis Penelitian ini adalah penelitian eksperimen dengan desain one-shot case study. Penelitian ini dilaksanakan di salah satu SD di Kecamatan Gubug Kabupaten Grobogan. Adapun teknik pengumpulan data yang digunakan adalah angket, tes dan dokumentasi. Sementara itu, data hasil penelitian dianalisis menggunakan uji prosentase angket, uji regresi dan uji t tes. Hasil penelitian ini menunjukkan bahwa: (1) Keaktifan siswa menggunakan Pembelajaran Kooperatif Learning Visual Auditory Kinestetik mempengaruhi nilai pemahaman konsep matematika. Berdasarkan perhitungan diperoleh nilai koefisien $(\mathrm{R})=0,825$ dengan $(\mathrm{R}$ Square $)=0,681$ $=68,1 \%$. Pada uji ANOVA menghasilkan $F_{\text {hitung }}=40,58$ dengan nilai sig $=0,000$. Dengan kriteria jika nilai sig $<\alpha$ maka koefisien korelasi tersebut signifikan dengan besar pengaruh $68,1 \%$. (2) Kemampuan pemahaman konsep matematika dengan menggunakan model Visual Auditory Kinestetik dapat memenuhi Kriteria Ketuntasan Minimal (KKM) diperoleh dari hasil uji t yang nilai Asymp $(2$-tailed $)=0,000<\alpha$.
\end{abstract}

Kata kunci: pembelajaran kooperatif visual auditory kinestetik, keaktifan siswa, kemampuan pemahaman konsep, matematika SD. 


\begin{abstract}
The purpose of this study is to determine the effect of student activeness on Learning Cooperative Learning Kinestetik Visual Auditory Model to Understanding Concept Mathematics of Primary School. Type of research is a experimental design using a oneshot case study design. Data collection techniques used are questionnaire, test, and documentation techniques. Meanwhile the research data is analyzed using the analysis of percentage questionnaire test, regression test and test. The results of this research show that: (1) Student activeness using Cooperative Learning Learning Visual Auditory Kinestetik influence comprehension value of math concept. Based on the calculation obtained coefficient value $(\mathrm{R})=0.825$ with $(\mathrm{R}$ Square $)=0.681=68.1 \%$. In ANOVA test yield Fcount $=40,58$ with value of $\operatorname{sig}=0,000$. By criterion if sig value $<\alpha$ then correlation coefficient is significant with big influence $68,1 \%$. (2) The ability to comprehend the concept of mathematics by using the Visual Auditory Kinesthetic model can fulfill the the minimum completeness criteria $(\mathrm{KKM})$ obtained from the result of $\mathrm{t}$ test which is Asymp value (2-tailed) $=0,000<\alpha$.
\end{abstract}

Keywords: cooperative learning visual kinesthetic auditorymodel, student activity, abilityof understanding concepts, mathematics elementary school.

\title{
PENDAHULUAN
}

Matematika merupakan mata pelajaran yang sangat bermanfaat bagi siswa. Mungkin saat ini sebagai siswa mereka belum menyadari, namun mengingat pentingnya matematika maka diharapkan siswa antusias dalam pembelajaran. Pada matematika diharapkan dapat membentuk pola pikir yang sistematis, logis, kritis dan penuh dengan kecermatan (Endrasmoyo, 2018). Jika dalam pembelajaran matematika khususnya di sekolah dasar tidak sejalan dengan perkembangan berfikir siswa, maka cenderung pembelajaran akan sulit diterima. Siswa menjadi kurang perhatian terhadap matematika bahkan terkadang membingungkan. Oleh karena itu, diperlukan pengalaman pembelajaran matematika yang bermakna dengan memberikan pemahaman konsep matematis dalam menyelesaikan masalah. Tujuan akhir pembelajaran matematika adalah agar konsep pembelajaran matematika di Sekolah dapat digunakan siswa dalam kehidupan seharihari. Selain itu, perlu dikembangkan ketrampilan pada matematika. Siswa diharapkan memiliki kemampuan intelektual, ketrampilan dan budi pekerti yang luhur.

Pembelajaran matematika pada sekolah dasar memiliki peran yang sangat besar dengan berbagai kegiatan kemampuan pada siswa, diantaranya ada kesanggupan berfikir dan kesanggupan memecahkan masalah di dalam berbagai kehidupan. Hal ini sesuai dengan Puspitasari (2012) yang mengatakan bahwa capaian pelajaran matematika ialah (1) mengerti rancangan matematika, menerangkan kaitannya antara rancangan dan mengaitkan rancangan dengan cara akurat, menarik, hemat sehingga cocok dalam memecahkann permasalahan; (2) Penggunaan jangkauan pemikiran pada karakter dan corak matematika dalam membuat kesimpulan menyusun penjelasan dan pernyataan gagasan matematika; (3) menyatukan pikiran 
dengan sketsa, lambang, atau alat peraga lain guna menjelaskan persoalan; (4) memecahkan persoalan yang berupa potensi mengetahui masalah, merencanakan model dan mengartikan solusi yang didapat.

Berdasarkan pengamatan pelaksanaan pembelajaran matematika di SD pada umumnya kurang diminati siswa. Hal ini dikarenakan pelajaran matematika kurang efektif. Ketika diadakan evaluasi sering menunjukan hasil dan nilai yang belum maksimal dengan belum memenuhi Kriteria Ketuntasan Minimal (KKM) yang disebabkan siswa tidak memahami konsep dasar pada matematika sehingga nilai KKM tidak terpenuhi. Pembelajaran matematika yang dilaksanakan belum memanfaatkan aktivitas siswa. Siswa menjadi pasif di kelas. Terkadang siswa disuruh diam dan mendegarkan penjelasan guru saja. Hal demikian membuat siswa tidak tertarik, bosan bahkan malas dalam pembelajaran matematika. Hal ini juga senada dengan penelitiannya (Arifuddin, 2016) yang mengungkapkan bahwa sebagian besar siswa merasa bosan dan jenuh dalam mengikuti pelajaran matematika. Padahal aktivitas manusia sehari-hari tidak terlepas dari pemanfaatan dan penerapan konsep-konsep yang ada di dalam matematika (Hariyono, 2018). Jika demikian sering dilakukan, maka wajar jika pemahaman materi matematika siswa menjadi rendah sehingga hasil belajar matematika menjadi kurang dan siswa menganggap matematika itu sulit.

Berdasarkan pengamatan yang peneliti lakukan di salah satu SD di Kecamatan Gubug Kabupaten Grobogan juga terlihat bahwa proses pembelajaran matematika yang berlangsung di sekolah tersebut masih konvensional. Guru lebih cenderung menjelaskan materi pelajaran dengan ceramah, guru jarang melibatkan siswa dalam proses pembelajaran sehingga pembelajaran menjadi membosankan. Pembelajaran matematika yang mempelajari ide-ide atau konsep abstrak cenderung dianggap sulit bagi siswa. Dalam pembelajaran guru belum menggunakan model, pendekatan dan berbagai inovasi pembelajaran. Metode ceramah yang sering dipakai guru membuat siswa menjadi pasif dalam pembelajaran. Siswa hanya menerima pelajaran yang disampaikan saja. Siswa tidak dapat mengembangkan kreatifitas dalam menggali pengetahuan mereka. Hal ini berdampak pada pemahaman konsep matematika yang dicapai siswa menjadi rendah. Jika hal ini berkelanjutan maka akan berpengaruh pada prestasi belajar siswa dan akhirnya tidak mencapai Kriteria Ketuntasan Minimum pada mata pelajaran matematika.

Salah satu materi dalam pelajaran matematika adalah pemahaman konsep bangun ruang. Peneliti mencoba memberikan soal dalam bentuk uraian secara tertulis kepada siswa. Soal pada observasi awal tersebut berupa gambar balok dan kubus yang digabungkan menjadi satu. Soal tersebut mengintruksikan agar siswa menghitung jumlah volume kedua bangun tersebut, namun banyak siswa yang belum paham terhadap konsep bangun tersebut untuk menyelesaikan soal 
bangun ruang. Terlihat siswa belum memahami konsep dengan membedakan mana panjang, lebar dan tinggi sebagaimana gambar 1 berikut.

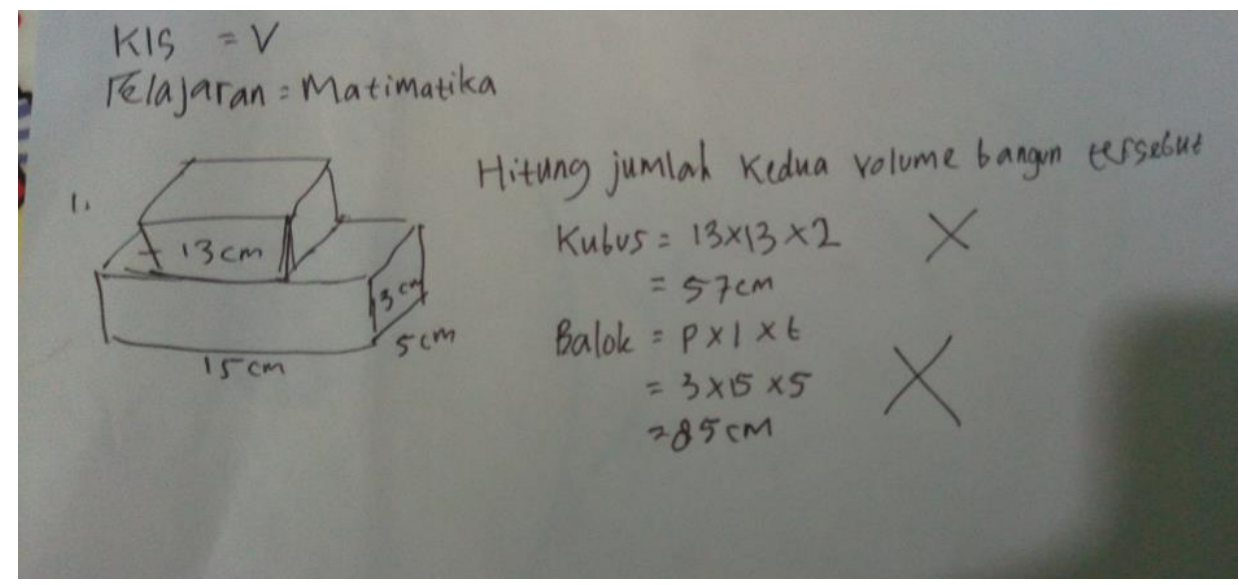

Gambar 1. Jawaban siswa pada soal matematika materi bangun ruang

Berdasarkan Gambar 1 terlihat bahwa pemahaman konsep matematika siswa masih rendah. Menghadapi masalah yang demikian, maka perlu solusi dalam penggunaan pembelajaran inovatif yang lebih menyenangkan dan menarik dan dapat membuat siswa aktif dalam beraktivitas belajar sehingga memahami konsep dasar matematika. Karena keaktifan siswa sangat diperlukan dalam pembelajaran. Keaktifan merupakan suatu kegiatan yang dinamis, bekerjakeras dalam mencapai suatu tujuan tertentu dengan ditandai adanya banyak gagasan yang dimunculkan dan kemampuan untuk menguraikan secara sitematis (Asriyah, 2014). Dan Keaktifan dalam hal ini adalah segala interaksi antara individu dengan individu dan individu dengan lingkungan yang membawa perubahan ke arah yang lebih baik (Megawati \& Annisa, 2012). Pembelajaran yang mengakomodir keaktifan siswa akan dapat mengembangkan kompetensi dan potensi siswa secara sadar disertai dengan pengembangan sumber belajar di lingkungan sekitar mereka, sehingga mereka dapat menyelesaikan permasalahan sehari-hari melalui berfikir sistematis, kritis dan tanggap melalui penelusuran informasi yang bermakna. Dalam sebuah penelitian dinyatakan bahwa metode dan media mempunyai peran yang sangat kuat. Sehingga dari hasil penelitian siswa memilih media yang membawa metode yang secara tidak sengaja menghasilkan kemampuan siswa yang lebih tinggi dan siswa menyukai metode dan media yang mereka anggap sebagai terstruktur dan direktif (Clark, 2007).

Salah satu model pembelajaran yang inovatif dan dapat meningkatkan aktivitas siswa dalam proses pembelajaran adalah model pembelajaran kooperatif. Coopeative learning adalah pembelajaran berkelompok dan bekerjasama serta saling membantu mengontruksi konsep dalam menyelesaikan persoalan (Shoimin, 2014). Kooperatif merupakan kegiatan kelompok yang dikemas melalui struktur ekternal yang difasilitasi oleh guru, dan siswa berperan penting dalam mengefektifkan pembelajaran dengan membangun lingkungan yang kooperatif dan kondusif 
(Huda, 2014). Dalam pembelajaran kooperatif ini guru berperan sebagai fasilitator yang akan membimbing siswa dalam bekerjasama dengan setiap kelompok yang heterogen. Pembelajaran kooperatif ini banyak jenisnya, salah satunya adalah model pembelajaran kooperatif Visual Auditory Kinestetik (VAK).

Model pembelajaran kooperatif Visual Auditory Kinestetik (VAK) merupakan salah satu model pembelajaran yang melibatkan siswa dalam tiga unsur, yaitu gaya belajar multi-sensorik yang menekankan pada penglihatan, pendengaran dan gerakan. Gaya belajar multi-sensorik ini menerapkan pembelajaran yang dapat mendorong siswa dan mengembangkan serta mengkombinasikan semua kemampuan yang dimiliki siswa dan dapat menutupi kekurangan yang dimiliki siswa. Dengan suasana yang menyenangkan maka siswa akan lebih aktif untuk belajar dan memudahkan memahami materi, begitu juga akan merangsang kemampuan kognitif, afektif dan psikomotorik siswa. Di samping itu, dengan gaya belajar yang multi sensorik ini guru juga dapat menggunakan modalitas dengan cara mengkombinasikan semua modalitas yang dimiliki oleh siswa sehingga dapat memberikan kemampuan yang lebih besar dan dapat saling menutupi kekurangan yang dimiliki masing-masing siswa (Huda, 2014). Dengan memanfaatkan semua modalitas yang ada, guru mempuyai banyak cara dalam pembelajaran. Misalnya terhadap siswa yang pembelajar visual guru dapat menggunakan gambar, video atau lainnya. Pada siswa dengan pembelajar auditory guru dapat menggunakan tape recorder. Sedangkan pada siswa pembelajar kinestetik guru dapat menggunakan beberapa kegiatan dalam pembelajarannya. Dengan demikian pembelajaran dengan gaya belajar visual auditory dan kinestetik dapat memberikan banyak kesempatan kepada siswa secara langsung dan bebas untuk mencapai pemahaman sehingga pembelajaran dapat berjalan efektif (Shoimin, 2014).

Model pembelajaran kooperatif VAK juga menegaskan bahwa siswa haruslah belajar dengan memanfaatkan alat indera yang dimiliki siswa. Dengan menggunakan model pembelajaran ini diharapkan siswa dapat bekerjasama untuk berkolaborasi dalam mencapai tujuan pembelajaran melalui pengembangan kemampuan dan ketrampilan yang ada pada diri siswa dengan sendirinya (Muammar, Harjono \& Gunawan, 2017). Model pembelajaran visual auditory dan kinestetik ini mempunyai banyak kelebihan, diantaranya 1) mengkombinasikan tiga bentuk gaya belajar yaitu visual, auditory dan kinestetik, 2) dapat mengembangkan dan melatih semua potensi yang dimiliki siswa, 3) Dapat pembelajaran siswa diberikan pengalaman secara langsung, 4) Dapat memfasilitasi gaya belajar yag dilimiki siswa, 5) tidak menghambat kemampuan siswa satu dengan lainnya walaupun memiliki potensi yang tinggi karena dalam pembelajaran ini dapat melayani siswa yang mempunyai kemampuan di atas rata-rata, dan 6) Dalam pembelajaran siswa dilibatkan secara maksimal dalam menemukan dan memahami konsep yang diberikan melaui diskusi aktif, eksperimen, demonstrasi dan observasi. 
Tahapan pembelajaran visual auditory dan kinestetik ada tiga, yaitu: 1) Visualization merupakan belajar mengguakan indera penglihatan dengan cara mengamati, mendemonstrasi, membaca, menggambardengan memanfaatkan alat peraga atau media. 2) Auditory kegiatan belajar dengan mengomunikasikan materi pelajaran dan bagaimana menerapkannya, memperagakan suatu gambar dan menjelaskan gambar tersebut kepada siswa lainnya, mendengarkan materi yang disampaikan dan merangkum informasi yang telah diperoleh. 3) Kinestetik belajar dengan mengalami, melakukan aktivitas atau gerakan anggota tubuh lainnya. Oleh karena itu, karena dalam proses pembelajaran semua komponen pembelajaran berperan penting untuk mencapai tujuan dari suatu pembelajaran, maka terdapat 4 proses belajar melewati rancangan tahapan perhatian, tahapan penyimpanan, tahapan mengembangbiakkan dan tahapan motivasi (Dahar, 2011).

Sehingga dapat disimpulkan bahwa model pembelajaran Visual, Auditory, Kinestetik dapat dijadikan salah satu solusi dalam mengatasi permasalahan di atas. Karena dalam pembelajaran Visual, Auditory, Kinestetik dapat dilakukan pada kelas dengan skala besar antara 20-40 siswa sebagaimana penelitian yang pernah dilakukan oleh (Rusdiyantiningsih, 2017) tentang pembelajaran Visual, Auditory, Kinesthetic (VAK) dapat meningatkan ketrampilan belajar siswa. Dalam penggunaannya model ini mengutamakan gaya belajar siswa dan aktivitas belajar siswa dipengaruhi oleh bagaimana gaya belajar yang dimiliki siswa tersebut untuk menerima dan mengolah informasi dalam pembelajaran yang dilakukan, apabila dalam pembelajaran sesuai dengan gaya belajar setiap siswa, maka aktivitas belajar akan lebih optimal. Dengan pembelajaran Visual, Auditory, Kinestetik siswa akan lebih aktif sehingga pembelajaran tidak membosankan, dan siswa dituntut untuk berfikir kreatif sehinga siswa mudah memahami konsep matematika. Penelitian ini bertujuan untuk mengetahui pengaruh penggunaan model pembelajaran model kooperatif learning visual auditory kinestetik terhadap keaktifan siswa dan pemahaman konsep matematika di sekolah dasar.

\section{METODE PENELITIAN}

Penelitian ini merupakan penelitian eksperimen dengan menggunakan pre-experimental design (nondesigns). Dikatakan pre eksperimental design (nondesigns) karena desain ini sedang ada variabel yang ikut berpengaruh pada bentuknya variabel terikat. Sehingga eksperimen yang merupakan variabel terikat tidak hanya dipengaruhi oleh variabel independen. Terjadi karena tidak ada variabel kemauan dan kelompok tidak dipilih secara acak. Bentuk desain ini menggunakan rancangan one-shot case study. Pada desain ini terdapat suatu kelompok yang dipakai untuk penelitian diberi treatment kemudian diteliti hasilnya (dengan perlakuan adalah variabel bebas dan hasilnya adalah variabel terikat). 
Penelitian ini dilaksanakan di salah satu SD di kecamatan Gubug kabupaten Grobogan dengan subjek penelitian siswa kelas V. Waktu penelitian kurang lebih 3 bulan pada semester II tahun ajaran 2017/2018, dan dilaksanakan sesuai jadwal pelajaran yang berlaku di sekolah. Populasi yang dipakai pada penelitian ini adalah siswa kelas V yang berjumlah 21 siswa, 11 siswa laki-laki dan 10 siswa perempuan. Adapun penentuan sampel yang digunakan pada penelitian ini menggunakan teknik non-probability sampling.

Teknik pengumpulan data yang digunakan pada penelitian ini adalah teknik berupa tes, observasi, dan dokumentasi. Pada penelitian ini instrumen penelitian yang digunakan yaitu instrumen lembar tes pemahaman konsep, lembar observasi keaktifan siswa dan dokumentasi selama proses pembelajaran berlangsung. Adapun lembar observasi berupa lembar pengamatan keaktifan siswa dalam mengikuti pembelajaran cooperative learning Tipe Visual Auditory Kinestetik. Indikator yang digunakan pada lembar pengamatan meliputi bagaimana siswa memperhatikan pembelajaran, mengemukakan pendapat, antusias dalam pembelajaran, siswa mengerjakan tugas yang diberkan guru, dan bagaimana siswa berdiskusi kelompok. Sebelum intrumen digunakan dalam penelitian maka akan diujicobakan terlebih dahulu. Adapun analisis uji coba instrumen yang di pakai adalah uji daya beda, uji reliabilitas, uji validitas dan uji tingkat kesukaran.

Selanjutnya, Analisis data yang dipakai meliputi analisis data awal dan analisis data akhir. Data awal yang digunakan pada penelitian ini adalah nilai ulangan harian siswa mata pelajaran matematika materi bangun datar pada semester gasal tahun ajaran 2017/2018. Analisis data awal hanya terdapat uji normalitas. Uji normalitas ditujukan untuk mengetahui apakah data berdistribusi normal atau tidak. Sebagai tindak lanjut penggunaan statistic parametric atau nonparametric. Sedangkan analisis data akhir terdiri dari uji normalitas, uji regresi dan uji one sample t test.

\section{HASIL DAN PEMBAHASAN}

Berdasarkan uji coba instrumen pada uji validitas diperoleh hasil dari 15 soal uji coba terdeteksi 3 soal tidak valid dan 12 soal valid. Berikut adalah kisi-kisi soal ujicoba yang berikan kepada siswa sebelum digunakan sebagai instrument penelitian. 


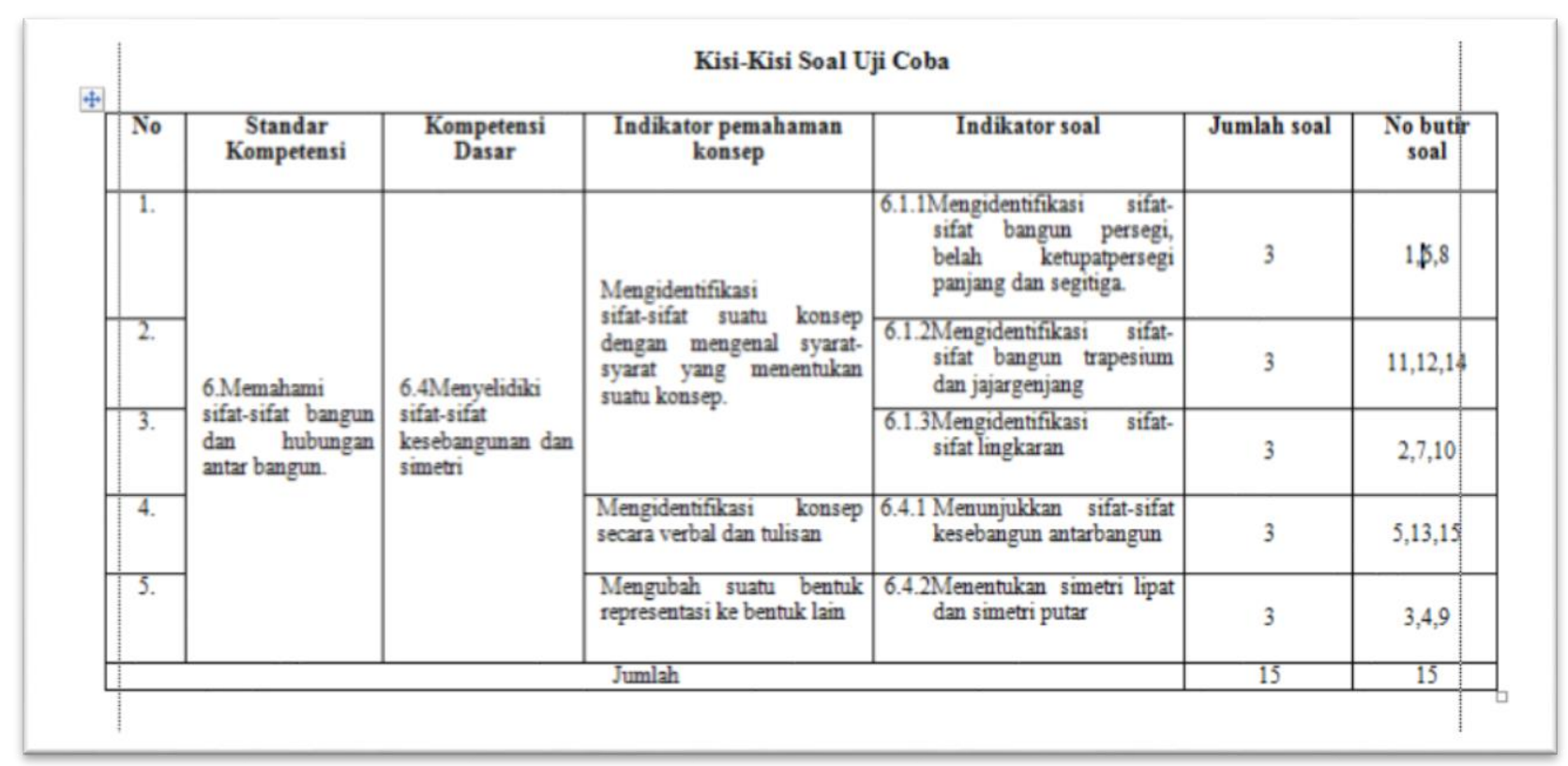

Gambar 2. Kisi-kisi soal Uji Coba

Sedangkan pada uji reliabilitas yang menggunakan Cronbach's Alphadari hasil perhitungan koeefisien reliabilitas sebesar 0,95 sehingga termasuk kategori sangat tinggi. Pada perhitungan Daya beda untuk mengetahui kemampuan suatu butir soal untuk dapat membedakan antara siswa dengan kemampuan tinggi rendah. Dari 15 butir soal terdapat 12 soal yang telah diujicobakan valid dan diperoleh 6 soal dengan kriteria jelek dan 5 soal dengan kriteria cukup dan 1 soal dengan kriteria baik. Hasil yang didapat dari uji coba instrumen diperoleh 3 soal berkriteria mudah serta 9 soal dengan kriteria cukup.

Analisis data awal dilakukan sebelum pengujian analisis data akhir. Data awal berupa nilai ulangan harian matematika Bab I pada kelas V di semester gasal tahun ajaran 2017/2018. Pengujian analisis data awal menggunakan uji normalitas. Pada penelitian ini uji normalitas data dilakukan dengan menggunakan uji liliefors diperoleh bahwa sebanyak 21 siswa memiliki jumlah nilai 1305. Mean atau nilai rata-rata sebesar 62,14 dengan simpangan baku 7,14; sig. sebanyak 0,$20 ; \alpha 0,05$ dan $\mathrm{L}_{\text {maks }} 0,13$. Maka dapat disimpulkan sebaran data berdistribusi normal karena sig. $=0,20>\alpha=0,05$

Pada data akhir yang didapat dari hasil observasi keaktifan siswa yang dilakukan untuk mengetahui keaktifan siswa selama pembelajaran berlangsung dan nilai pemahaman konsep matematika. Analisis data akhir terdiri dari uji normalitas. Pada penelitian ini uji normalitas data dilakukan dengan menggunakan uji liliefors. Pada penelitian ini ujinormalitas data akhir keaktifan siswa dilakukan dengan menggunakan uji liliefors, dapat dijelaskan bahwa sebanyak 21 siswa memiliki jumlah nilai 1285. Mean atau nilai rata-rata sebesar 6,26 dengan simpangan baku 6,26; sig. sebanyak 0,20; $\alpha 0,05$ dan $\mathrm{L}$ maks 0,12 . Maka dapat disimpulkan sebaran data berdistribusi normal karena sig. $=0,20>\alpha=0,05$. Sedangkan penelitian uji normalitas data akhir 
pemahaman konsep matematika dilakukan dengan menggunakan uji liliefors. Diperoleh bahwa sebanyak 21 siswa memiliki jumlah nilai 1735. Mean atau nilai rata-rata sebesar 82,61 dengan simpangan baku 7,32; sig. sebanyak 0,20; $\alpha$ 0,05 dan L maks 0,14. Maka dapat disimpulkan sebaran data berdistribusi normal karena sig. $=0,20>\alpha=0,05$

Data hasil observasi keaktifan siswa dan pemahaman konsep berdistribusi normal, maka selanjutnya dilakukan uji hipotesis. Uji hipotesis meliputi uji hipotesis 1 dan uji hipotesis 2. Pada Uji hipotesis 1 berupa uji pengaruh dengan menggunakan uji regresi linier sederhana untuk menguji adakah pengaruh penggunaan model pembelajaran kooperatif tipe Visual Auditory Kinestetik terhadap keaktifan siswa dan pemahaman konsep matematika kelas V. Dihasilkan nilai $A=23,58$. Sedangkan $B=0,96$ koeefisien $(R)=0,82$ dengan koefisien determinasi $(R$ Square $)=0,68=68,1 \%$. Sedangkan nilai koefisien korelasi ditunjukkan uji ANOVA yang menghasilkan pengujian $\mathrm{F}_{\text {hitung }}=40,58$ dengan nilai sig=0,00. Kriteria pengujiannya adalah jika nilai sig $<\alpha$ maka koefisien korelasi tersebut signifikan. Karena nilai sig $=0,00<\alpha=0,05$ maka koefisien korelasi untuk persoalam diatas signifikan dengan besar pengaruh $68,1 \%$. Maka disimpulkan bahwa terdapat pengaruh penggunaan model pembelajaran kooperatif tipe Visual Auditory Kinestetik terhadap keaktifan siswa dan pemahaman konsep matematika kelas V.

Sedangkan uji hipotesis 2 berupa uji one sample $t$ test digunakan untuk menguji ketuntasan belajar individual rata-rata kemampuan pemahaman konsep matematika. Dengan tujuan untuk mengetahui siswa kelas eksperimen yang telah mendapatkan pembelajaran dengan model kooperative Learning Tipe Visual Auditory Kinestetik sudah memenuhi Kriteria Ketuntasan Minimal sebesar 70. Dihasilkan bahwa banyaknya data 21 siswa dengan rata-rata 82,61 dan simpangan baku=7,32; sedangkan pada output kedua, ditampilkan Test Value $=70$ dengan nilai Thitung= 7,89; nilai Asymp (2-tailed) $=0,00<\alpha$ maka Ha ditolak. Karena nilai nilai Asymp (2-tailed) $=0,00<0,05$ maka Ho di terima. Dengan demikian dapat diperoleh bahwa pemahaman konsep matematika siswa kelas $\mathrm{V}$ dengan menggunakan model Visual Auditory Kinestetik dapat memenuhi KKM. Hal ini dikarenakan pada model kooperative Learning Tipe Visual Auditory Kinestetikpembelajaran sangat menarik bagi siswa. Sebagaimna pendapat Sari (2017) yang menyatakan bahwa pembelajaran sebaiknya disajikan dengan menggunakan sebuah pembelajaran yang memiliki daya tarik bagi siswa sehingga tujuan pembelajaran tercapai.

Berdasarkan hasil penelitan di atas, dapat diambil pembahasan bahwa sikap keaktifan siswa setelah mendapat pelajaran dengan model pembeleajaran kooperatif Visual Auditory Kinestetik berdampak positif. Hal ini terlihat ketika siswa memperhatikan pembelajaran menggunakan model Visual Auditory Kinestetik, siswa mampu mengemukakan pendapat, kemudian antusias siswa dalam mengikuti pembelajaran, keaktifan siswa dalam mengerjakan 
tugas yang diberikan guru dan juga diskusi dalam kelompok. Berikut prosentase keaktifan siswa dalam proses pembelajaran di kelas.

Tabel 1. Prosentase Keaktifan Siswa

\begin{tabular}{clc}
\hline No & \multicolumn{1}{c}{ Indikator } & Prosentase \% \\
\hline 1 & $\begin{array}{l}\text { Memperhatikan pembelajaran dengan } \\
\text { menggunakan model VAK }\end{array}$ & $78 \%$ \\
\hline 2 & Mengemukakan pendapat & $70 \%$ \\
\hline 3 & $\begin{array}{l}\text { Antusias dalam mengikuti pembelajaran dengan } \\
\text { menggunakan model VAK }\end{array}$ & $83 \%$ \\
\hline 4 & Mengerjakan tugas yang diberikan guru & $85 \%$ \\
\hline 5 & Diskusi kelompok & $83 \%$ \\
\hline
\end{tabular}

Berdasarkan Tabel 1 tentang prosentase keaktifan siswa diperoleh data tertinggi sebesar $85 \%$ pada indikator siswa mengerjakan tugas yang diberikan guru. Dengan demikian keaktifan siswa pada pembelajaran dengan menggunakan model pembelajaran kooperatif tipe Visual Auditory Kinestetik mempengaruhi nilai pemahaman konsep matematika. Dibuktikan pada uji regresi linier sederhana. Dihasilkan nilai koeefisien $(R)=0,825$ determinasi $(\mathrm{R}$ Square $)=0,681=$ 68,1\%. Sedangkan nilai koefisien korelasi ditunjukkan uji ANOVA yang menghasilkan pengujian Fhitung $=40,58$ skor sig=0,000. Kriteria penggujiannya ialah apabila nilai sig $<\alpha$ maka koefisien hubungan tersebut penting. Karena skor sig $=0,000<\alpha=0,05$ maka koefisien korelasi untuk persoalam diatas signifikan dengan besar perubahan 68,1\%. Data tentang keaktifan siswa dapat disajikan sebagaimana grafik 1 berikut.

presentase indikator keaktifan siswa

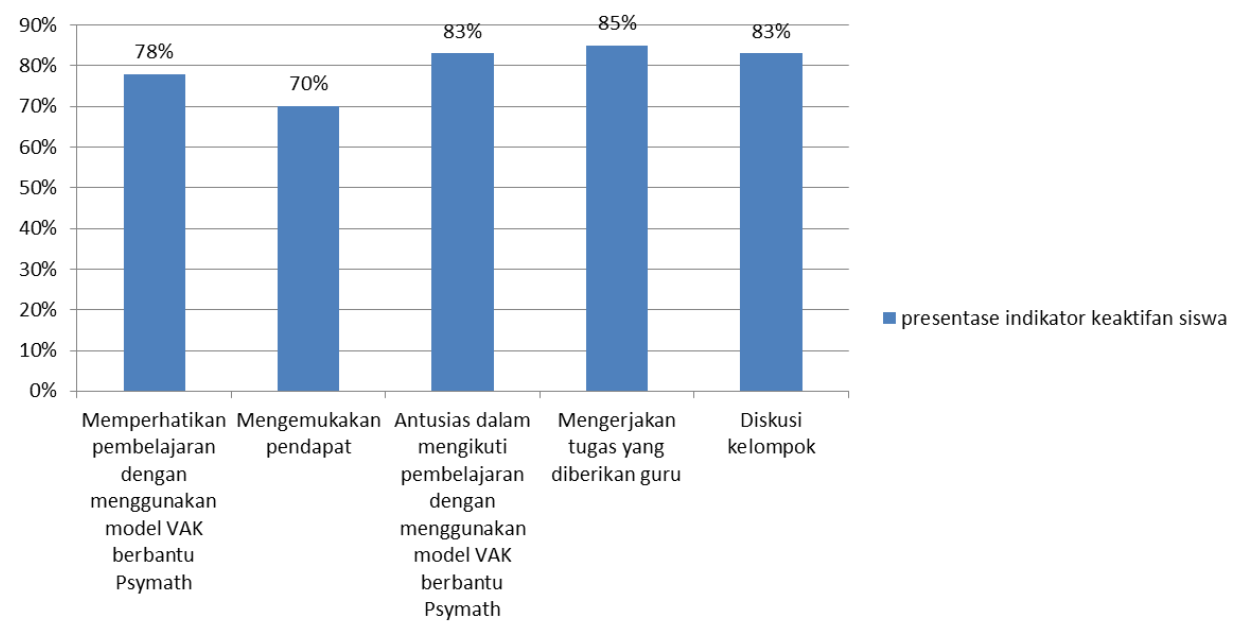

Grafik 1. Prosentase keaktifan siswa

Berdasarkan grafik 1 terlihat bahwa prosentase indikator keaktifan siswa yang tertinggi adalah menyelesaikan kewajiban yang diberikan pengajar. Sedang prosentase indikator keaktifan siswa yang paling rendah adalah mengemukakan pendapat. Akan tetapi secara keseluruhan prosentase keaktifan siswa berpengaruh positif pada pengetahuan rancangan matematika. Hasil penelitian yang diperoleh diperkuat dengan penelitian sebelumnya yang 
dilakukan oleh (Ghufira, 2016) yang menyatakan bahwa model pembelajaran Visual Auditory Kinesthetic (VAK) berpengaruh terhadap aktivitas belajar tematik siswa rombel III SD sehingga model pembelajaran VAK dapat mempengaruhi aktivitas belajar tematik peserta didik. Hal ini sejalan dengan pendapat Shoimin (2014) bahwa gaya belajar visual auditory dan kinestetik memberikan kesempatan siswa dengan belajar secara langsung dan bebas menggunakan modalitas yang dimilikinya untuk mencapai pemahaman dan pembelajaran yang efektif. Ketuntasan pemahaman konsep matematika dengan menggunakan model Visual Auditory Kinestetik telah memenuhi ketuntasan belajar.

Selanjutnya, untuk mengukur kemampuan pemahaman konsep siswa digunakan tes pemahaman konsep. tes pemahaman konsep tersebut berupa soal uraian yang terdiri dari 12 butir soal. Berikut adalah salah satu contoh hasil pekerjaan siswa dalam menyelesaikan sebagian soal pemahaman konsep.

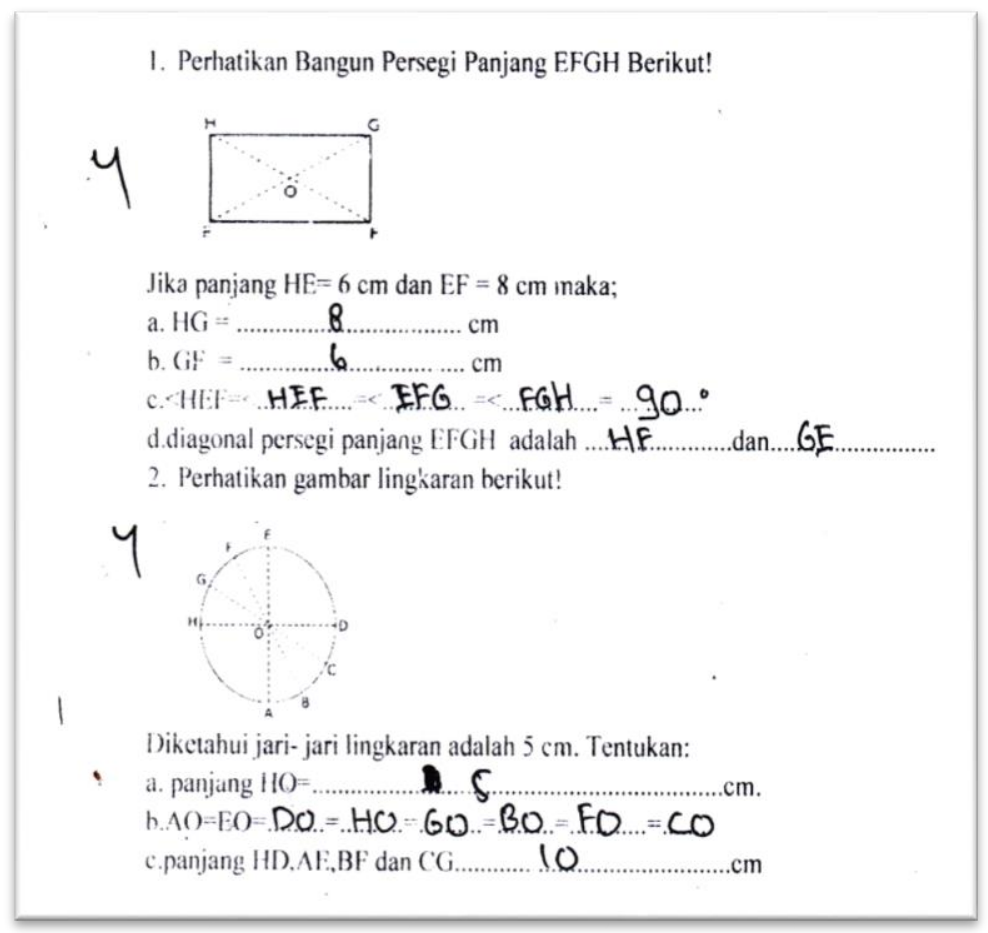

Gambar 3. Hasil Pekerjaan siswa

Adapun hasil tes pemahaman konsep yang diberikan siswa diperoleh analisis per indikator sebagai berikut.

Tabel 2. Indikator pemahaman konsep

\begin{tabular}{clc}
\hline No & \multicolumn{1}{c}{ Indikator } & $\begin{array}{c}\text { prosentase } \\
\%\end{array}$ \\
\hline 1 & $\begin{array}{l}\text { Diidentifikasi ciri rancangan dengan mengenal } \\
\text { tuntutan yang menentukan suatu rancangan }\end{array}$ & $86 \%$ \\
\hline 2 & Mengidentifikasi konsep secara verbal dan tulisan & $85 \%$ \\
\hline 3 & Merubah suatu konsepmewkili ke konsep lain & $66 \%$ \\
\hline
\end{tabular}


Berdasarkan tabel 2 tentang indikator pemahaman konsep matematika diperoleh prosentase tertinggi sebesar $86 \%$, yakni indikator keterangan diidentifikasi ciri rancangan dengan mengenal tuntutan yang menentukan suatu rancangan. Data tersebut telah dibuktikan pada uji t, dengan ukuran percobaan yang skor Asymp (2-tailed) $=0,000<\alpha$ maka Ha ditolak. Karena nilai nilai Asymp (2-tailed) $=0,000<0,05$ maka Ho di terima artinya kemampuan pemahaman konsep matematika siswa pada model pembelajaran Visual Auditory Kinestetik dapat memenuhi KKM.

Adapun hasil tes pemahaman konsep matematika yang diselesaikan siswa dapat disajikan dalam bentuk grafik 2 sebagai berikut.

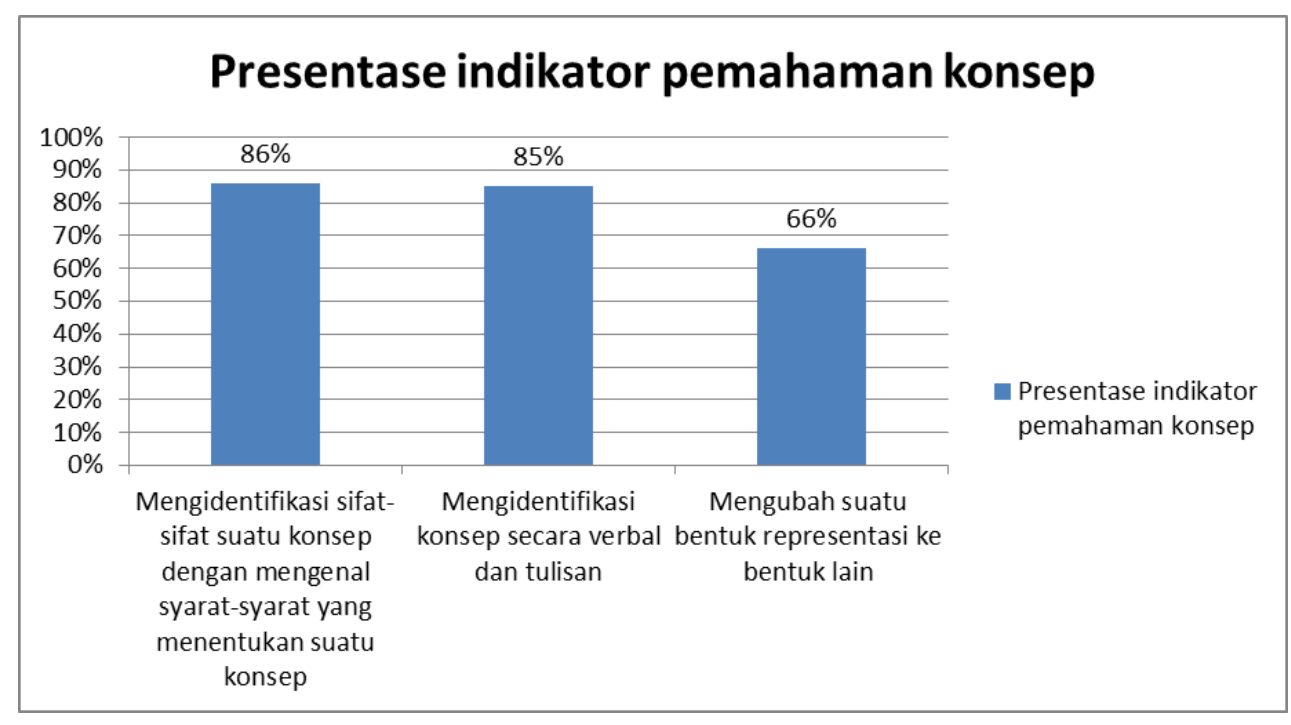

Grafik 2. Prosentase indikator pemahaman konsep 1

Berdasarkan Grafik 2 terlihat rata-rata indikator pemahaman konsep yang tertinggi adalah mengidentifikasi ciri rancangan dengan tuntutan yang menentukan rancangan. Sedangkan rata pengetahuan rancangan yang paling rendah adalah mengubah suatu bentuk reprosentase ke bentuk yang lain. Akan tetapi secara rata-rata keseluruhan nilai pemahaman konsep matematika dapat memenuhi KKM.

Berdasarkan hasil tes pemahaman konsep matematika, kesanggupan pengetahuan konsep matematika siswa kelas V memakai pola Visual Auditory Kinestetik dapat memenuhi KKM. Hasil penelitian ini diperkuat oleh penelitian sebelumnya yang dilakukan oleh (Rahayu \& Ana, 2017) bahwa rata- rata hasil belajar siswa yang didapatkan melalui penerapan jarak konseptual gaya belajar (VAK) Visual Auditory kinestetik lebih baik dari rata-rata skor belajar matematika yang diperoleh melalui pendekatan langsung. Hal ini juga senada dengan pendapat Heruman (2016) yang menyatakan bahwa pemahaman konsep yaitu pembelajaran konsep yang baru, apabila siswa belum belajar rancangan tadi. Penumbuhan rancangan bawah adalah jalan yang menyambungkan kesanggupan kemampuan kognitif kongkret dengan rancangan awal yang 
bersifat tidak terbentuk pada matematika sehingga dapat memakai media agar menolong gambaran pikiran siswa.

Untuk memahami matematika dapat melalui tindakan atau presepsi terhadap matematika. (Eric, 2003). Aktivitas dalam pembelajaran matematika mempunyai peran penting untuk mengantarkan siswa dalam memahami matematika. Tujuan pembelajaran matematika tidak hanya untuk perkembangan kognitif saja namun bisa dikembangkan pada ranah afektif dan psikomotorik. Berdasarkan penelitian (Amir, 2015) disimpulkan bahwa hasil analisis yang diperoleh pada pembelajaran matematika menyatakan bahwa terdapat gaya belajar siswa yang beranekaragam yakni visual, auditory dan kinestetik yang mempunyai aktivitas berbeda-beda seperti pada gaya kinestetik siswa cenderung aktif dan kritis sehingga kemampuan psikomotorik akan dimanfaatkan dalam meningkatkan kemampuan kognitif mereka.

Keaktifan dan aktivitas pada siswa setelah mendapat pembelajaran Visual Auditory Kinestetik berdampak positif. Hal ini terlihat ketika siswa memperhatikan pembelajaran menggunakan model Visual Auditory Kinestetik, siswa mampu mengemukakan pendapat, kemudian antusias siswa dalam mengikuti pembelajaran, keaktifan siswa dalam mengerjakan tugas yang diberikan guru dan juga diskusi dalam kelompok.Indikator keaktifan siswa diperoleh data tertinggi $85 \%$ pada indikator siswa mengerjakan tugas yang diberikan guru. Dengan demikian keaktifan siswa dalam pembelajaran model Visual Auditory Kinestetik dapat mempengaruhi nilai pemahaman konsep matematika. Hasil ini sesuai dengan penelitian yang dilakukan oleh (Sancoko, Kurniawan, Pos, \& Kemiri, 2013) yang mengungapkan bahwa aktivitas siswa pada pembelajaran VAK mengalami peningkatan pada tiap pertemuannya sehingga berpengaruh terhadap prestasi belajar yang semakin meningkat. Dibuktikan pada uji regresi linier sederhana. Dihasilkan nilai koefisien $(R)=0,825$ dengan koefisien determinasi $(R$ Square) $=0,681=68,1 \%$. Sedangkan nilai koefisien korelasi ditunjukkan uji ANOVA yang menghasilkan pengujian Fhitung $=40,58$ dengan nilai sig $=0,000$.

Berdasarkan kriteria pengujian sig $<\alpha$ maka koefisien korelasi tersebut signifikan, sehingga diperoleh perhitungan dengan nilai sig $=0,000<\alpha=0,05$ maka koefisien korelasi untuk persoalan di atas signifikan dengan besar pengaruh 68,1\%. Sehingga dapat disimpulkan bahwa terdapat pengaruh keaktifan siswa yang signifikasi dengan model pembelajaran Visual Auditory Kinestetik terhadap pemahaman konsep matematika kelas V. Hal ini dapat disebabkan karena pada pembelajaran Visual Auditory Kinestetik menjadikan lingkungan belajar di kelas berpusat pada siswa dan guru mengakomidir semua kemampuan siswa baik di pembelajaran visual, auditory dan kinestetik sehingga terjadi interaksi sosial yang baik, sebagaimana penelitian yag dilakukan (Ulia, 2018) menyatakan bahwa tingkat perkembangan aktual dan tingkat 
perkembangan potensial dapat ditingkatkan melalui suasana pembelajaran dan interaksi sosial guru dan siswa yang baik.

Berdasarkan analisis data diperoleh prosentase tertinggi pada indikator kemampuan pemahaman konsep sebesar $86 \%$ pada indikator mengidentifikasi sifat-sifat suatu konsep dengan mengenal syarat-syarat yang menentukan suatu konsep. Data tersebut telah dibuktikan pada uji t, dengan kriteria pengujian yang nilai Asymp $(2$-tailed) $=0,000<\alpha$ maka Ha ditolak. Karena nilai nilai Asymp (2-tailed) $=0,000<0,05$ maka Ho di terima artinya rata-rata kemampuan pemahaman konsep matematika siswa kelas V dengan menggunakan model Visual Auditory Kinestetik dapat memenuhi KKM. Maka Ho: $\mu \mathrm{o}>70$, (rata-rata kemampuan pemahaman konsep matematika siswa kelas $\mathrm{V}$ dengan menggunakan model Visual Auditory Kinestetikdapat memenuhi KKM > 70). Rata-rata indikator pemahaman konsep yang tertinggi adalah mengidentifikasi sifat-sifat suatu konsep dengan syarat-syarat yang menentukan konsep. Sedangkan rata-rata pemahaman konsep yang paling rendah adalah mengubah suatu bentuk reprosentase ke bentuk yang lain. Akan tetapi secara keseluruhan rata-rata pemahaman konsep matematika dapat memenuhi KKM.

\section{SIMPULAN}

Keaktifan siswa menggunakan model Pembelajaran Kooperatif Learning Tipe Visual Auditory Kinestetik mempengaruhi nilai pemahaman konsep matematika. Dihasilkan nilai koeefisien $(\mathrm{R})=0,825$ determinasi $(\mathrm{R}$ Square $)=0,681=68,1 \%$. Sedangkan nilai koefisien korelasi ditunjukkan uji ANOVA diperoleh pengujian $F_{\text {hitung }}=40,58$ skor sig=0,000. Penetapan penggujiannya adalah jika nilai sig $<\alpha$ maka koefisien korelasi tersebut signifikan. Karena nilai sig $=0,000<\alpha=0,05$ maka koefisien korelasi untuk persoalam diatas signifikan dengan besar pengaruh $68,1 \%$. Maka terdapat pengaruh keaktifan siswa yang signifikasi terhadap model pembelajaran kooperatif learning tipe Visual Auditory Kinestetik terhadap pemahaman konsep matematika kelas V.

Pemahaman konsep matematika dengan menggunakan model Visual Auditory Kinestetikmengenai materi bangun datar telah memenuhi KKM dibuktikan pada uji t, Ukuran pengujian yang nilai Asymp (2-tailed) $=0,000<\alpha$ maka Ha ditolak. Karena nilai nilai Asymp (2tailed) $=0,000<0,05$ maka Ho di terima artinya rata-rata kemampuan pemahaman konsep matematika siswa kelas $\mathrm{V}$ dengan menggunakan model Visual Auditory Kinestetik dapat memenuhi KKM. Maka rata-rata kemampuan pemahaman konsep matematika siswa kelas V dengan menggunakan model Visual Auditory Kinestetik dapat memenuhi KKM>70.

Berdasarkan penelitian yang telah dilaksanakan, bahwa penerapan model pembelajaran Kooperatif tipe Visual Auditory Kinestetik berpengaruh terhadap pemahaman konsep 
matematika materi bangun datar di Sekolah Dasar, maka disarankan: (1) Guru sebaiknya mulai menetapkan model pembelajaran yang inovatif misalnya seperti model pembelajaran kooperatif tipe Visual Auditory Kinestetik untuk menghindari siswa yang kurang aktif dalam kegiatan diskusi dan sebaiknya lebih meningkatkan kemampuan dalam pemahaman konsep pada pelajaran matematika karena dengan menguasainya akan berpengaruh pada hasil belajar matematika yang optimal sehingga terpenuhinya KKM dalam pembelajaran. (2) Guru sebaiknya selalu mengawasi aktivitas siswa supaya siswa yang berkesulitan dapat langsung bertanya sehingga waktu yang digunakan lebih efisien.

\section{DAFTAR PUSTAKA}

Amir, M. F. (2015). Proses Berpikir Kritis Siswa Sekolah Dasar dalam Memecahkan Masalah Berbentuk Soal Cerita Matematika Berdasarkan Gaya Belajar. Jurnal Math Educator Nusantara, 1(2), 159-170

Arifuddin, A. (2016). Pembelajaran Matematika Model Quantum Teaching dengan Pendekatan Realistik untuk Meningkatkan Kemampuan Pemahaman Konsep Peserta Didik. Al Ibtida: Jurnal Pendidikan Guru MI, 3(2), 186-196.

Asriyah, N. (2014). Penggunaan Model Mnemonik Dengan Media Lcd Proyektor Untuk Meningkatkan Keaktifan Dan Hasil Belajar Ips Kelas V Semester II SD Negeri 2 Bandungrejo Kalinyamatan Tahun 2013 - 2014. Guru SD Negeri 2 Bandungrejo Kec. Kalinyamatan Kab. Jepara.

Clark, E. R. (2007). Reconsidering Research on Learning from Media. Review of Educational Research Journal, 53(4), 445-459

Dahar, W.R. (2011). Teori-teori Belajar dan Pembelajaran. Jakarta: Erlangga.

Endrasmoyo, W. (2018). Caktramatemawiku Inovasi Cerdas Matematika Dasar. Jakarta: Indocamp.

Eric, G. (2003). Teaching and Learning Mathematics for Social Justice in an Urban, Latino School. Journal for Research in Mathematics Education, 34(1), 37-73.

Ghufira, S. (2016). Pengaruh Model Pembelajaran Visual Auditory Kinesthetic (Vak) Terhadap Aktivitas Belajar Tematik Peserta Didik Kelas III Sd Negeri 1 Haduyang Tahun Pelajaran 2015/2016. Skripsi pada FKIP Universitas Lampung Bandar lampung. Tidak diterbitkan.

Hariyono, M. (2018). Pembelajaran Matematika Realistik Berbantuan Multimedia Client Server (MCS) untuk Meningkatkan Kemampuan Pemecahan Masalah dan Keyakinan Matematika. Jurnal Pendas, 2(1), 23-33.

Heruman. (2016). Model Pembelajaran Matematika di Sekolah Dasar. Bandung: Remaja Rosdakarya.

Huda, M. (2014). Model-Model Pengajaran Dan Pembelajaran Isu-Isu Metodis Dan Paradigmatis. Yogyakarta: pustaka pelajar

Megawati, N \& Annisa. (2012). Model Pembelajaran Kooperatif Tipe Team Assisted Individualization (TAI) Dalam Meningkatkan Keaktifan Siswa dan Hasil Belajar 
Akuntansi Siswa Kelas XI IPS 1 SMA Negeri 1 Banjarnegara Tahun Ajaran 2011/2012. Jurnal Pendidikan Akuntansi Indonesia, 10(01), 162-180.

Muammar, H., Harjono, A., \& Gunawan, G. (2017). Pengaruh Model Pembelajaran Assure dan Pengetahuan Awal Terhadap Hasil Belajar IPA-Fisika Siswa Kelas VIII SMPN 22 Mataram. Jurnal Pendidikan Fisika dan Teknologi, 1(3), 166172.

Puspitasari, Reni., Sularmi \& Djaelani. (2012). Penggunaan Model Kooperatif Teknik Make a Match Untuk Meningkatkan Kemampuan Memecahkan Masalah Soal Cerita dalam Matematika. Jurnal Didaktika Dwija Indria, 2(20), 1-5.

Rahayu, S. \& Ana. (2017). Pembelajaran Matematika Melalui Pendekatan Kontekstual Dengan Gaya Belajar Vak (Visual Auditory Kinestetik). Jurnal Edumath, 3(2), 129-137.

Rusdiyantiningsih, A. (2017). Pengaruh Metode Visual, Auditory, Kinesthetic (Vak) Terhadap Peningkatan Keterampilan Menulis Bilangan 1-10 Bagi Anak Tunagrahita Kelas Dii/C Slb Negeri Sragen Tahun Ajaran 2016/2017. Skripsi pada FKIP Universitas Sebelas Maret Surakarta: tidak diterbitkan.

Sancoko, M. A., Kurniawan, L., Pos, J. J. K., \& Kemiri, S. (2013). Studi Komparatif Strategi Belajar ARIAS dan Strategi Belajar VAK (A Comparative Study Of ARIAS Learning Strategies And VAK Learning Strategies). Jurnal Pendidikan Matematika STIKIP PGRI Sidoarjo, 1(1), 61-74.

Sari, Y. (2017). Pengembangan Bahan Ajar Komik IPA Dengan Penanaman Nilai Budai Pada Siswa Kelas IV Sekolah Dasar. Jurnal Pendidikan Sekolah Dasar, 3(2), 129-142.

Shoimin, A. (2014). Model Pembelajaran Inovatif dalam Kurikulum 2013 Yogyakarta: Ar-ruzz Media.

Ulia, N. (2018). Efektivitas Colaborative Learning Berbantuan Media Short Card Berbasis IT Terhadap Pemahaman Konsep Matematika. Jurnal Pendas, 3(2), 111. 